\title{
The incidence of PALB2 c.3113G>A in women with a strong family history of breast and ovarian cancer attending Familial Cancer Centres in Australia.
}

\author{
*Zhi L Teo ${ }^{1}$, *Sarah D Sawyer ${ }^{2}$, Paul A James ${ }^{2,3}$, Gillian Mitchell ${ }^{2,3}$, Alison H \\ Trainer $^{2,4}$, Geoffrey J Lindeman ${ }^{4,5,6}$, Kylie Shackleton ${ }^{4}$, Linda Cicciarelli ${ }^{2}$, and \\ Melissa C Southey ${ }^{1 \wedge}$. \\ ${ }^{1}$ Genetic Epidemiology Laboratory, Department of Pathology, The University of \\ Melbourne, Victoria 3010, Australia \\ ${ }^{2}$ Familial Cancer Centre The Peter MacCallum Cancer Centre, St Andrews Place, \\ East Melbourne, Victoria 3002, Australia \\ ${ }^{3}$ The Sir Peter MacCallum Department of Oncology, The University of \\ Melbourne, Victoria 3010, Australia \\ ${ }^{4}$ Familial Cancer Centre, The Royal Melbourne Hospital, Parkville, Victoria \\ 3050, Australia \\ ${ }^{5}$ The Walter and Eliza Hall Institute of Medical Research, Parkville, Victoria, \\ 3052, Australia \\ ${ }^{6}$ The Department of Medicine, The University of Melbourne, Victoria 3010, \\ Australia \\ *contributed equally to this work. \\ ${ }^{\wedge}$ Corresponding author \\ Phone: (03) 83444895
}

Fax: (03) 83444004

Email: msouthey@unimelb.edu.au

\begin{abstract}
The familial aggregation of breast cancer has been well-described with approximately $25 \%$ of breast cancers attributable to inherited mutations in currently known breast cancer susceptibility genes. PALB2 c.3113G >A (p.Trp1038*) is a protein-truncating mutation which has been associated with high estimated risk of breast cancer in Australian women $(91 \% ; 95 \% \mathrm{CI}=$ 44-100) to age 70 years. This study screened for $P A L B 2$ c.3113G $>A$ in germline DNA representing 871 unrelated individuals from "high-risk" breast and/or ovarian cancer families evaluated in the setting of a Familial Cancer Centre in Australia. The PALB2 c.3113G>A mutation was identified in eight of 871 probands $(0.92 \%)$ from these families. Median age of diagnosis was 42 years. Five of these eight women had contra-lateral breast cancers. Available data suggests that the $P A L B 2$ c. $3113 \mathrm{G}>\mathrm{A}$ is a rare mutation with estimated breast cancer risks similar in magnitude to that associated with $B R C A 2$ mutations. Although the proportion of high-risk women carrying this PALB2 mutation is low, research efforts should continue in order to effect its translation into clinical genetic testing practice.
\end{abstract}

Keywords:

PALB2

Hereditary breast cancer

Familial cancer centre

BRCA1 and BRCA2 mutation negative 


\section{Letter to the Editor,}

Breast cancer is a common disorder with a strong hereditary component resulting in at least a two-fold increase in risk of the disease for women with an affected first-degree relative [1-8]. Approximately $20 \%$ of women in the population are reported to have one or more first-degree relatives affected with breast cancer [9]. The familial aggregation of breast cancer is thought to be largely due to heritable factors [10] yet mutations in BRCA1 and BRCA2 account for only around $16 \%$ of the genetic contribution to familial breast cancer [11,12]. Recent studies have investigated the possibility that rare germline mutations in additional genes explain the remaining familial risk. This has led to the description of a number of new breast cancer susceptibility genes including ATM [13], CHEK2 [14], BRIP1 [15] and PALB2 [16].

Normal PALB2 function is essential for homologous recombination (HR) repair of DNA double strand breaks where the protein acts as a bridge, forming an integral link between BRCA1 and BRCA2 [17,18]. Mono-allelic mutations in $P A L B 2$ have been estimated to confer an increased risk of breast cancer of two- to six-fold [16] but the statistical approach applied had some limitations [19].

Modified segregation analysis involving breast cancer cases, unselected for family history and their first- and second-degree relatives estimated the penetrance of the PALB2 c.3113G >A mutation to age 70 years to be $91 \%$, albeit with wide confidence intervals (95\% confidence interval $=44-100)$ [20]. The confidence interval of the estimate encompasses and is, therefore, comparable to the average estimated risk for breast cancer for BRCA2 mutation carriers to the age of 71[21]. However, the segregation pattern in some families cannot exclude the possibility of additional genetic breast cancer risk modifiers being present in these families.

The $P A L B 2$ c.3113G>A (p.Trp1038*) mutation appears to be a recurrent mutation associated with a high estimated risk of breast cancer. Hence, we aimed to establish the contribution of PALB2 c.3113G>A to breast cancer in the group of women assessed as 'high risk' on the basis of their personal and family history of breast and/or ovarian cancer following clinical assessment at a Familial Cancer Centre (FCC). To determine the prevalence of $P A L B 2$ c. $3113 \mathrm{G}>\mathrm{A}$ in this clinicbased population, targeted screening for this mutation was performed in unrelated 
probands from the Victorian Familial Breast Cancer Cohort (VFBCC) of "high risk" breast and/or ovarian cancer families [22]. The cohort includes individuals assessed by one of the three Familial Cancer Centers in Victoria, Australia (The Peter MacCallum Cancer Centre, The Royal Melbourne Hospital, and the Victorian Clinical Genetic Service) between 1997 and 2010. For all families, the cancer history was assessed through questionnaire and person consultation and was verified through local cancer registries or individual medical records. Initially, classification of a proband as 'high risk' was based on national guidelines requiring a family history involving a minimum of two, first- or second-degree relatives with breast cancer with at least one additional risk factor (additional affected close relatives, diagnosis before 40 years, multiple primary breast or ovarian cancers in one individual, male breast cancer, or Ashkenazi Jewish ancestry). From 2003, individuals were classified as 'high risk' where the proband was estimated to have a $\geq 10 \%$ probability of a mutation in BRCAl or $B R C A 2$ by an established mutation prediction tool $[23,24]$.

Diagnostic testing was conducted on all DNA samples provided by probands. Prior to 2003, diagnostic testing was a combination of PTT, dHPLC and Sanger sequencing of all exons. After this date, diagnostic testing consisted of Sanger sequencing of all coding and flanking intronic regions of BRCA1 and BRCA2 and SALSA $^{\circledR}$ Multiplex Ligation-dependent Probe Amplification (MLPA) ${ }^{\circledR}$ analysis (MRC-Holland, Amsterdam, Netherlands). A proportion of probands underwent retrospective MLPA analysis; consequently, $83 \%$ of the cohort completed screening for large deletions or rearrangements within the BRCA1 and BRCA2 genes. Within the cohort, $7 \%$ of probands only underwent diagnostic testing for Ashkenazi Jewish founder mutations via Sanger sequencing.

Ethics approval was obtained from human research ethic committees at all sites and at the University of Melbourne prior to study commencement.

A total of 972 individuals were recruited by the VFBCC. Of these, 95 were excluded as i) their DNA samples were found to be unsuitable for screening $(\mathrm{n}=2)$, ii) they were identified as carriers of BRCA1, BRCA2, or TP53 mutations $(n=22)$, iii) they were not affected with breast cancer or that their cancer status could not be determined ( $n=71)$ iv) or they failed genotyping $(n=6)$. (Figure 1). The remaining 871 individuals included 848 women and 23 men who were affected with breast and/or ovarian cancer. DNA extracted from peripheral blood 
of the participants was whole genome amplified (WGA) using the Repli-G Phimediated amplification system (Qiagen, Hilden, Germany) and analysed for PALB2 c.3113G>A using the Custom Taqman ${ }^{\circledR}$ SNP Genotyping Assay (Life Technologies, Carlsbad, California, USA). The Taqman ${ }^{\circledR}$ probe-based assays were performed as per manufacturer's instructions on the LightCycler480 (Roche Applied Science, Penzberg, Upper Bavaria, Germany). Non-WGA DNA samples were used to confirm positive results of the Taqman ${ }^{\circledR}$ probe-based assay by Sanger sequencing. DNA samples from six individuals $(0.6 \%)$ failed the Taqman ${ }^{\circledR}$ probe-based assays.

Of the 871 unrelated participants who were successfully genotyped for PALB2 c. $3113 \mathrm{G}>\mathrm{A}$, eight women $(0.92 \%)$ were identified as carriers. The median age of onset of the eight mutation carriers was 42 (33-49) years compared to a median age of onset of $45(20-84)$ years in non-carriers $(p=0.07)$. (Table 1$)$.

Information on the segregation of the PALB2 c.3113G $>$ A mutation in the families of the carriers was limited, as blood samples of the relatives were typically not available. However, one female sibling of an affected PALB2 c.3113G $>$ A carrier (Figure 2h), diagnosed with a grade 2 infiltrating ductal carcinoma $(\mathrm{ER}+/ \mathrm{PR}+/ \mathrm{HER} 2+)$ at the age of 36 years was also a participant in the VFBCC; genotyping confirmed that she also carried the PALB2 c.3113G>A mutation.

Figure 2 shows the pedigrees of the carriers of $P A L B 2$ c. $3113 \mathrm{G}>\mathrm{A}$. Five of the eight carriers had two primary diagnoses of breast cancer. The median age of onset for the second diagnoses of these five unrelated participants was 51 (range, 38-58). Five of the nine PALB2 c.3113G>A carriers were affected by contralateral breast cancer $(63 \%)$ compared to $123 / 740(17 \%)(p=0.009$, Fischer's exact test) of the non-carrier women with breast cancer. This finding supports the association with contra-lateral breast cancer that has been reported previously [25].

There were a total of 14 breast cancer diagnoses among the nine PALB2 mutation carriers who had personal diagnoses of breast cancer. Pathology reports were available for 11 of the 14 cancers; ten cases were infiltrating ductal carcinomas and one an infiltrating lobular carcinoma (Table 2). Information on histological grade and receptor status was either unavailable or incomplete on two of the pathology reports. For the remaining nine tumours, seven of the cancers were 
either histological grade 2 or 3 using the modified Bloom-Richardson system [26], and two of the nine were triple negative, i.e. negative for estrogen and progesterone receptors (ER and PR), and human epidermal growth factor receptor 2 (HER2) expression (Table 2).

Our study demonstrates that the PALB2 c.3113G>A mutation contributes to the risk of breast cancer in approximately $1 \%$ of the high-risk breast and/or ovarian cancer families presenting to FCCs in Victoria, Australia. The mutation was found at a similar level in two other studies that involved breast and/or ovarian cancer multiple-case families attending clinical genetics services in Australia and/or New Zealand [20,27]. Table 3 compares the carrier frequency of PALB2 c.3113G>A observed in this study with the four previous studies.

The prevalence of $P A L B 2$ c. $3113 \mathrm{G}>\mathrm{A}$ observed in Victorian FCCs, together with its high estimated breast cancer risk [20] that is similar, on average, to that conferred by BRCA2 mutations [21], supports the progress of $P A L B 2$ c.3113G>A into a clinical translation phase. Nonetheless, the translation of PALB2 genetic testing into routine clinical practice will be complex as the value of a negative pre-symptomatic test for family members is not always clear. This is a challenging and dynamic phase that requires further studies to exclude the presence of other susceptibility alleles, health economic analyses and educational activities to ensure smooth and appropriate use of this new genetic information.

The authors declare that they have no conflict of interest.

\author{
Abbreviations: \\ CI: Confidence interval \\ FCC: Familial Cancer Centre \\ VFBCC: Victorian Familial Breast Cancer Cohort \\ WGA: Whole genome amplified \\ ER: Estrogen receptor \\ PR: Progesterone receptor \\ HER2: Human epidermal growth factor-2 \\ MLPA: Multiplex Ligation-dependent Probe Amplification
}


Acknowledgements:

This study was supported by the Victorian Cancer Agency (CTTS07, EOI09-50); the National Health and Medical Research Council (NHMRC) via project grant APP1029974, Senior Research Fellowship (M.C.S.), Dora Lush Postgraduate Scholarship (Z.L.T.), Principal Research Fellowship (G.J.L.) and IRIISS; University of Melbourne, Postgraduate Faculty Research Scholarship (Z.L.T.) and the Victorian Breast Cancer Research Consortium and Operational Infrastructure Support. M.C.S. and G.J.L are Victorian Breast Cancer Research Consortium Group Leaders.

We wish to thank A/Prof Ian Campbell and the VBCRC Cancer Genetics Laboratory, Peter MacCallum Cancer Centre for their assistance with the preparation of the DNA samples (Victorian Breast Cancer Research Consortium). We also thank Prof Ingrid Winship for her contribution and critical assessment of the manuscript. The authors gratefully acknowledge the contribution of the staff at the Familial Cancer centres who assisted in the annotation of the families and the staff of the Genetic Epidemiology Laboratory who supported aspects of the bench work. 
References:

1. Turnbull C, Rahman N (2008) Genetic predisposition to breast cancer: Past, present, and future. Annual Review of Genomics and Human Genetics 9:321-345. doi:10.1146/annurev.genom.9.081307.164339

2. Dite GS, Jenkins MA, Southey MC, Hocking JS, Giles GG, McCredie MRE, Venter DJ, Hopper JL (2003) Familial risks, early-onset breast cancer, and BRCA1 and BRCA2 germline mutations. Journal of the National Cancer Institute 95 (6):448-457

3. Lynch HT, Watson P, Conway T, Fitzsimmons ML, Lynch J (1988) Breastcancer family history as a risk factor for early onset breast-cancer. Breast Cancer Research and Treatment 11 (3):263-267

4. Houlston RS, McCarter E, Parbhoo S, Scurr JH, Slack J (1992) Family history and risk of breast-cancer. Journal of Medical Genetics 29 (3):154-157

5. Colditz GA, Rosner BA, Speizer FE (1996) Risk factors for breast cancer according to family history of breast cancer. Journal of the National Cancer Institute 88 (6):365-371

6. Frank TS, Deffenbaugh AM, Hulick M, Gumpper K (1999) Hereditary susceptibility to breast cancer: Significance of age of onset in family history and contribution of BRCA1 and BRCA2. Disease Markers 15 (1-3):89-92

7. Negri E, Braga C, LaVecchia C, Franceschi S, Parazzini F (1997) Family history of cancer and risk of breast cancer. International Journal of Cancer 72 (5):735-738

8. Poole CA, Byers T, Calle EE, Bondy J, Fain P, Rodriguez C (1999) Influence of a family history of cancer within and across multiple sites on patterns of cancer mortality risk for women. American Journal of Epidemiology 149 (5):454-462

9. Beral V, Bull D, Doll R, Peto R, Reeves G (2001) Familial breast cancer: collaborative reanalysis of individual data from 52 epidemiological studies including 58209 women with breast cancer and 101986 women without the disease. Lancet 358 (9291):1389-1399

10. Hemminki K, Granstrom C (2003) Familial breast cancer: scope for more susceptibility genes? Breast Cancer Research and Treatment 82 (1):17-22. doi:10.1023/B:BREA.0000003871.38587.8b

11. Peto J, Collins N, Barfoot R, Seal S, Warren W, Rahman N, Easton DF, Evans

C, Deacon J, Stratton MR (1999) Prevalence of BRCA1 and BRCA2 gene mutations in patients with early-onset breast cancer. Journal of the National Cancer Institute 91 (11):943-949. doi:10.1093/jnci/91.11.943

12. Cui JS, Antoniou AC, Dite GS, Southey MC, Venter DJ, Easton DF, Giles GG, McCredie MRE, Hopper JL (2001) After BRCA1 and BRCA2-what next? Multifactorial segregation analyses of three-generation, population-based Australian families affected by female breast cancer. American Journal of Human Genetics 68 (2):420-431

13. Renwick A, Thompson D, Seal S, Kelly P, Chagtai T, Ahmed M, North B, Jayatilake H, Barfoot R, Spanova K, McGuffog L, Evans DG, Eccles D, Easton DF, Stratton MR, Rahman N (2006) ATM mutations that cause ataxiatelangiectasia are breast cancer susceptibility alleles. Nature Genetics 38 (8):873875

14. Meijers-Heijboer H, van den Ouweland A, Klijn J, Wasielewski M, de Snoo A, Oldenburg R, Hollestelle A, Houben M, Crepin E, van Veghel-Plandsoen M, Elstrodt F, van Duijn C, Bartels C, Meijers C, Schutte M, McGuffog L, Thompson D, Easton DF, Sodha N, Seal S, Barfoot R, Mangion J, Chang-Claude J, Eccles D, Eeles R, Evans DG, Houlston R, Murday V, Narod S, Peretz T, Peto J, Phelan C, Zhang HX, Szabo C, Devilee P, Goldgar D, Futreal PA, Nathanson 
KL, Weber BL, Rahman N, Stratton MR (2002) Low-penetrance susceptibility to breast cancer due to CHEK2*1100delC in noncarriers of BRCA1 or BRCA2 mutations. Nature Genetics 31 (1):55-59. doi:10.1038/ng879

15. Seal S, Thompson D, Renwick A, Elliott A, Kelly P, Barfoot R, Chagtai T, Jayatilake H, Ahmed M, Spanova K, North B, McGuffog L, Evans DG, Eccles D, Easton DF, Stratton MR, Rahman N (2006) Truncating mutations in the Fanconi anemia J gene BRIP1 are low-penetrance breast cancer susceptibility alleles. Nature Genetics 38 (11):1239-1241. doi:10.1038/ng1902

16. Rahman N, Seal S, Thompson D, Kelly P, Renwick A, Elliott A, Reid S, Spanova K, Barfoot R, Chagtai T, Jayatilake H, McGuffog L, Hanks S, Evans DG, Eccles D, Easton DF, Stratton MR (2007) PALB2, which encodes a BRCA2interacting protein, is a breast cancer susceptibility gene. Nature Genetics 39 (2): $165-167$

17. Sy SMH, Huen MSY, Chen JJ (2009) PALB2 is an integral component of the BRCA complex required for homologous recombination repair. Proceedings of the National Academy of Sciences of the United States of America 106 (17):71557160. doi:10.1073/pnas.0811159106

18. Zhang F, Ma JL, Wu JX, Ye L, Cai H, Xia B, Yu XC (2009) PALB2 Links

BRCA1 and BRCA2 in the DNA-Damage Response. Current Biology 19 (6):524529. doi:10.1016/j.cub.2009.02.018

19. Byrnes GB, Southey MC, Hopper JL (2008) Are the so-called low penetrance breast cancer genes, ATM, BRIP1, PALB2 and CHEK2, high risk for women with strong family histories? Breast Cancer Res 10 (3):208. doi:bcr2099 [pii] $10.1186 /$ bcr2099

20. Southey M, Teo Z, Dowty J, Odefrey F, Park D, Tischkowitz M, Sabbaghian N, Apicella C, Byrnes G, Winship I, Baglietto L, Giles G, Goldgar D, Foulkes W, Hopper J, kConFab, the Breast Cancer Family R (2010) A PALB2 mutation associated with high risk of breast cancer. Breast Cancer Research 12 (6):R109 21. Antoniou A, Pharoah PDP, Narod S, Risch HA, Eyfjord JE, Hopper JL, Loman N, Olsson H, Johannsson O, Borg A, Pasini B, Radice P, Manoukian S, Eccles DM, Tang N, Olah E, Anton-Culver H, Warner E, Lubinski J, Gronwald J, Gorski B, Tulinius H, Thorlacius S, Eerola H, Nevanlinna H, Syrjakoski K, Kallioniemi OP, Thompson D, Evans C, Peto J, Lalloo F, Evans DG, Easton DF (2003) Average risks of breast and ovarian cancer associated with BRCA1 or BRCA2 mutations detected in case series unselected for family history: A combined analysis of 22 studies. American Journal of Human Genetics 72 (5):1117-1130

22. Sawyer S, Mitchell G, McKinley J, Chenevix-Trench G, Beesley J, Chen XQ, Bowtell D, Trainer AH, Harris M, Lindeman GJ, James PA (2012) A Role for Common Genomic Variants in the Assessment of Familial Breast Cancer. . Journal of Clinical Oncology

23. Berry DA, Iversen ES, Jr., Gudbjartsson DF, Hiller EH, Garber JE, Peshkin BN, Lerman C, Watson P, Lynch HT, Hilsenbeck SG, Rubinstein WS, Hughes KS, Parmigiani G (2002) BRCAPRO validation, sensitivity of genetic testing of BRCA1/BRCA2, and prevalence of other breast cancer susceptibility genes. J Clin Oncol 20 (11):2701-2712

24. NBOCC (2012) Advice about familial aspects of breast cancer and epithelial ovarian cancer: a guide for health professionals.

http://canceraustralia.nbocc.org.au/.

25. Tischkowitz M, Capanu M, Sabbaghian N, Li L, Liang X, Vallee MP, Tavtigian SV, Concannon P, Foulkes WD, Bernstein L, Bernstein JL, Begg CB 
(2012) Rare germline mutations in PALB2 and breast cancer risk: a populationbased study. Hum Mutat 33 (4):674-680. doi:10.1002/humu.22022

26. Elston CW, Ellis IO, Pinder SE (1999) Pathological prognostic factors in breast cancer. Critical Reviews in Oncology Hematology 31 (3):209-223.

doi:10.1016/s1040-8428(99)00034-7

27. Wong MW, Nordfors C, Mossman D, Pecenpetelovska G, Avery-Kiejda KA, Talseth-Palmer B, Bowden NA, Scott RJ (2011) BRIP1, PALB2, and RAD51C mutation analysis reveals their relative importance as genetic susceptibility factors for breast cancer. Breast Cancer Research and Treatment 127 (3):853-859. doi:10.1007/s10549-011-1443-0

29. Casadei S, Norquist BM, Walsh T, Stray S, Mandell JB, Lee MK, Stamatoyannopoulos JA, King MC (2011) Contribution of Inherited Mutations in the BRCA2-Interacting Protein PALB2 to Familial Breast Cancer. Cancer Research 71 (6):2222-2229. doi:10.1158/0008-5472.can-10-3958

30. 1. Mann GJ, Thorne H, Balleine RL, Butow PN, Clarke CL, Edkins E, Evans GM, Fereday S, Haan E, Gattas M, Giles GG, Goldblatt J, Hopper JL, Kirk J, Leary JA, Lindeman G, Niedermayr E, Phillips KA, Picken S, Pupo GM, Saunders C, Scott CL, Spurdle AB, Suthers G, Tucker K, Chenevix-Trench G (2006) Analysis of cancer risk and BRCA1 and BRCA2 mutation prevalence in the kConFab familial breast cancer resource. Breast Cancer Research 8 (1):R12. doi:R12 
Fig. 1 Flowchart of the probands included in the study

Fig. 2 Pedigrees of carriers of $P A L B 2$ c. $3113 \mathrm{G}>$ A. Symbols with filled lower left quadrant: cancer other than breast cancer. Symbols that are completely filled: breast cancer. Arrow: Proband. UK: Unknown cancer or unknown age of diagnosis. +: Genotyped and identified as a carrier of PALB2 c. $3113 \mathrm{G}>$ A. -: Genotyped and identified as a non-carrier of $P A L B 2$ c.3113G $>$ A. ${ }^{\text {a }}$ : previously reported by Southey et al [20]

Table 1: Demographics of unrelated participants screened for $P A L B 2$ c.3113G $>A$

\begin{tabular}{|c|c|c|}
\hline & $\begin{array}{c}\text { Non-carriers of } \\
\text { PALB2 } \\
\text { c.3113G }>A\end{array}$ & $\begin{array}{c}\text { Carriers of } \\
\text { PALB2 } \\
\text { c.3113G }>A\end{array}$ \\
\hline Total number of participants & 863 & 8 \\
\hline Deceased & 39 & 2 \\
\hline Age at last contact ${ }^{a}$ & 55 & 51 \\
\hline Follow up from diagnosis ${ }^{a}$ & 9 & 6 \\
\hline Unilateral Breast Cancer & 618 & 3 \\
\hline Age of first diagnosis (median, range) & $45(20-84)$ & $42(33-49)$ \\
\hline Bilateral breast cancer & 120 & 5 \\
\hline Age of first diagnosis (median, range) & $45(23-71)$ & $46(32-49)$ \\
\hline Age of second onset (median, range) & $52(27-85)$ & $51(38-58)$ \\
\hline Breast and/or ovarian cancers & 29 & 0 \\
\hline Age of first diagnosis (median, range) & $53(28-75)$ & \\
\hline Ovarian Cancer & 57 & 0 \\
\hline Age of first diagnosis (median, range) & $55(27-80)$ & \\
\hline Male Breast Cancers & 23 & 0 \\
\hline Age of first diagnosis (median, range) & $59(31-77)$ & \\
\hline Other cancer Diagnosis & 16 & 0 \\
\hline Family History, $1^{\text {st }}-3^{\text {rd }}$ degree relatives ( $n$, mean) & & \\
\hline Female Breast Cancer & $1545(1.8)$ & $27(3.4)$ \\
\hline Male Breast Cancer & $25(0.03)$ & 0 \\
\hline Ovarian cancer & $165(0.2)$ & $2(0.3)$ \\
\hline Isolated cases ${ }^{b}$ & 6 & 0 \\
\hline Total no. 1st-3rd degree Relatives & 22754 & 312 \\
\hline
\end{tabular}

${ }^{\mathrm{a}}$ Median, years. ${ }^{\mathrm{b}}$ No 1 st-3rd degree relatives affected by breast or ovarian cancer

Table 2: Histopathological features of tumours from carriers of PALB2 c.3113G>A

\begin{tabular}{|c|c|c|c|c|c|c|c|c|}
\hline & \multirow[t]{2}{*}{ Cancer } & \multirow{2}{*}{$\begin{array}{c}\text { Age of } \\
\text { diagnosis }\end{array}$} & \multirow{2}{*}{$\begin{array}{c}\text { Histopathology } \\
\text { subtype }\end{array}$} & \multirow{2}{*}{$\begin{array}{c}\text { DCIS } \\
\text { (presence) }\end{array}$} & \multirow[t]{2}{*}{ Grade } & \multicolumn{3}{|c|}{$\begin{array}{c}\text { Hormone Receptor } \\
\text { Status } \\
\end{array}$} \\
\hline & & & & & & ER & PR & HER2 \\
\hline 1 & Breast & 33 & Ductal -Invasive & Yes & III & neg & neg & neg \\
\hline 2 & Breast & 42 & Ductal -Invasive & Yes & - & pos & pos & - \\
\hline 3 & Breast & 44 & Ductal -Invasive & Yes & III & pos & pos & pos \\
\hline 4 & Breast & 48 & Ductal -Invasive & - & I & pos & neg & neg \\
\hline
\end{tabular}




\begin{tabular}{|c|c|c|c|c|c|c|c|c|} 
& Breast & 51 & - & - & - & - & - & - \\
\hline \multirow{2}{*}{5} & Breast & 49 & Ductal -Invasive & Yes & II & pos & neg & neg \\
\cline { 2 - 9 } & Breast & 58 & - & - & - & - & - & - \\
\hline \multirow{2}{*}{6} & Breast & 46 & Lobular -Invasive & Yes & - & - & - & - \\
\cline { 2 - 9 } & Breast & 52 & Ductal -Invasive & Yes & III & neg & pos & neg \\
\hline \multirow{2}{*}{7} & Breast & 38 & Ductal -Invasive & Yes & III & neg & neg & neg \\
\cline { 2 - 9 } & Breast & 38 & Ductal -Invasive & - & - & - & - & - \\
\hline \multirow{2}{*}{$8^{\text {a }}$} & Breast & 32 & - & - & - & - & - & - \\
\cline { 2 - 9 } & Breast & 46 & Ductal -Invasive & Yes & III & pos & neg & neg \\
\hline $9^{\text {a }}$ & Breast & 36 & Ductal -Invasive & Yes & II & pos & pos & pos \\
\hline
\end{tabular}

DCIS: Ductal carcinoma in situ. ER: Estrogen receptor. PR: Progesterone receptor. HER2: Human epidermal growth receptor -2. -Unable to locate cancer pathology report. ${ }^{\text {a}}$ Related carriers, mutation carrier 8 is the proband.

\begin{tabular}{|c|c|c|c|}
\hline Reference & Ascertainment & Geographic region & $\begin{array}{c}\text { PALB2 c.3113G >A } \\
\text { carrier frequency } \\
\text { in cases }\end{array}$ \\
\hline $\begin{array}{l}\text { Rahman et al., } \\
2007\end{array}$ & $\begin{array}{l}\text { Women with breast cancer and a family } \\
\text { history of breast cancer. All breast cancer } \\
\text { cases were previously screened for mutations } \\
\text { and large deletions/duplications in } B R C A 1 \text { and } \\
B R C A 2 \text { and were found to be negative. }\end{array}$ & United Kingdom & 2/923 (0.23\%) \\
\hline $\begin{array}{l}\text { Southey et al., } \\
2010\end{array}$ & $\begin{array}{l}\text { This study reported the carrier frequencies of } \\
\text { PALB2 c.3113G }>A \text { in two study groups. A } \\
\text { population-based study that recruited women } \\
\text { with a histologically confirmed first primary } \\
\text { invasive cancer of the breast regardless of } \\
\text { family history and women with breast cancer } \\
\text { and a family history of breast cancer recruited } \\
\text { through Australian and New Zealand cancer } \\
\text { clinics by the Kathleen Cuningham Foundation } \\
\text { Consortium for Research in Familial Breast } \\
\text { Cancer [30]. }\end{array}$ & $\begin{array}{l}\text { Population-based } \\
\text { study cohort: } \\
\text { Metropolitan areas of } \\
\text { Victoria and New } \\
\text { South Wales, } \\
\text { Australia } \\
\text { Multiple-case study } \\
\text { cohort: Australia and } \\
\text { New Zealand }\end{array}$ & $\begin{array}{c}\text { Population-based : } \\
\text { 5/1,403 (0.4\%) } \\
\text { Multiple-case: } \\
\text { 8/778 (1.0\%) }\end{array}$ \\
\hline $\begin{array}{l}\text { Wong et al., } \\
\quad 2011\end{array}$ & $\begin{array}{l}\text { Women with breast or ovarian cancer ( } 68 \\
\text { breast cancer and two ovarian cancer cases). } \\
\text { These cases had an early age at diagnosis } \\
\text { (under the age of } 50 \text { years or pre- } \\
\text { menopausal), a strong family history of breast } \\
\text { and ovarian cancers in first- or second-degree } \\
\text { relatives and were previously screened for } \\
\text { mutations in BRCA1 and BRCA2 and were } \\
\text { found to be non-carriers. }\end{array}$ & $\begin{array}{c}\text { New South Wales, } \\
\text { Australia }\end{array}$ & $1 / 70(1.4 \%)^{\mathrm{a}}$ \\
\hline $\begin{array}{l}\text { Casadei et al., } \\
\quad 2011\end{array}$ & $\begin{array}{l}\text { Study cohort consisted of breast cancer cases } \\
\text { with at least two first- or second-degree } \\
\text { relative with breast cancer. The breast cancer } \\
\text { cases were screened for and not found to be } \\
\text { carriers of } B R C A 1 \text { or } B R C A 2 \text { mutations. } 172 \\
\text { breast cancer cases of the study cohort (all } \\
\text { females) were of the Ashkenazi Jewish } \\
\text { ancestry and } 972 \text { (959 females and } 13 \text { males) } \\
\text { were of other unselected ancestries. }\end{array}$ & USA & $\begin{array}{l}\text { Ashkenazi Jewish } \\
\text { ancestry: 0/172 } \\
\text { Unselected } \\
\text { ancestries: } \\
\text { 5/972 (0.5\%) }\end{array}$ \\
\hline This study & $\begin{array}{l}\text { Study cohort consisted of breast cancer cases } \\
\text { with at least two first- or second-degree }\end{array}$ & Victoria, Australia & $8 / 878$ (0.91\%) \\
\hline
\end{tabular}




\begin{tabular}{|l|l|l|l|}
\hline & $\begin{array}{l}\text { relatives with breast cancer with at least one } \\
\text { additional risk factor: } 1 \text { ) additional affected } \\
\text { close relatives; } 2 \text { ) diagnosis before } 40 \text { years; 3) } \\
\text { multiple primary breast or ovarian cancers in } \\
\text { one individual; 4) male breast cancer; or 5) } \\
\text { Ashkenazi Jewish ancestry. }\end{array}$ & & \\
\hline
\end{tabular}

${ }^{a}$ Mutation carrier is affected with breast cancer. 
Click here to download Manuscript: Figure 1 revised.pptx

Click here to view linked References

Unrelated 'high-risk' probands of the Victorian FCC Breast

Cancer Cohort $(n=972)$

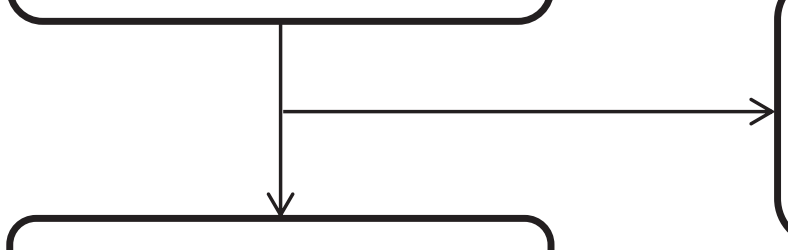

\section{Excluded $(n=95)$}

-DNA unsuitable for screening $(\mathrm{n}=2)$

- Identified as carriers of $B R C A 1, B R C A 2$

and TP53 mutations $(\mathrm{n}=22)$

-Did not fit study criteria $(n=71)$

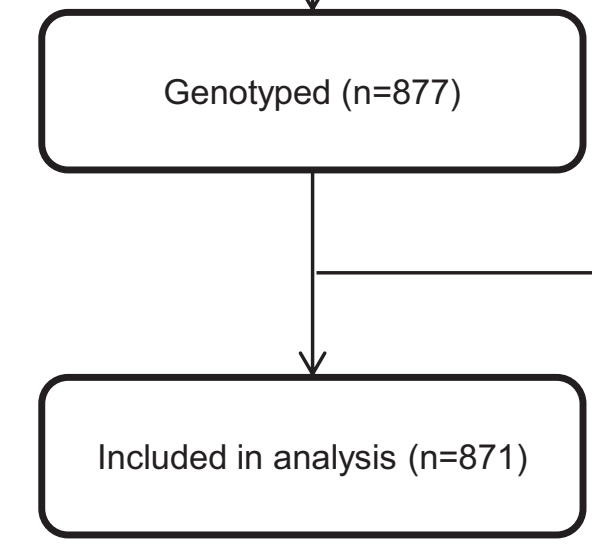

Excluded $(n=6)$

- Genotyping was unsuccessful $(n=6)$ 
Manuscript

Click here to download Manuscript: Figure 2.ppt

Click here to view linked References

a)

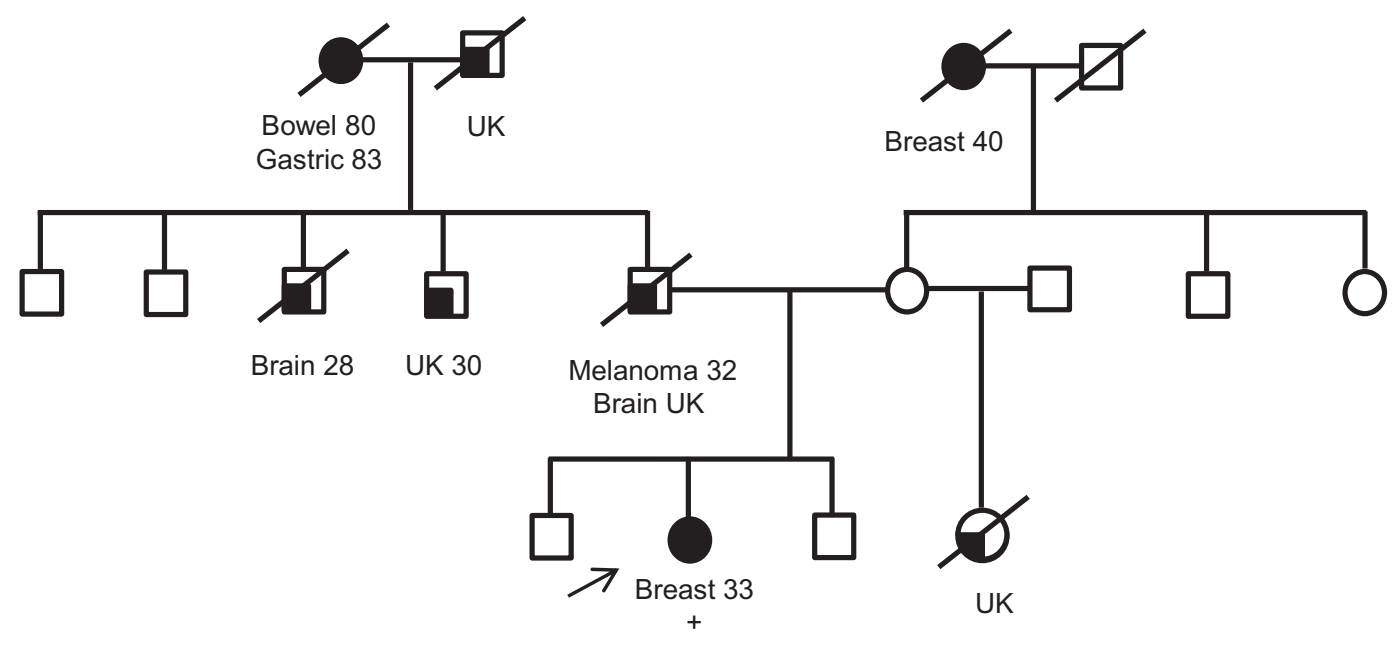

b) $)^{a}$

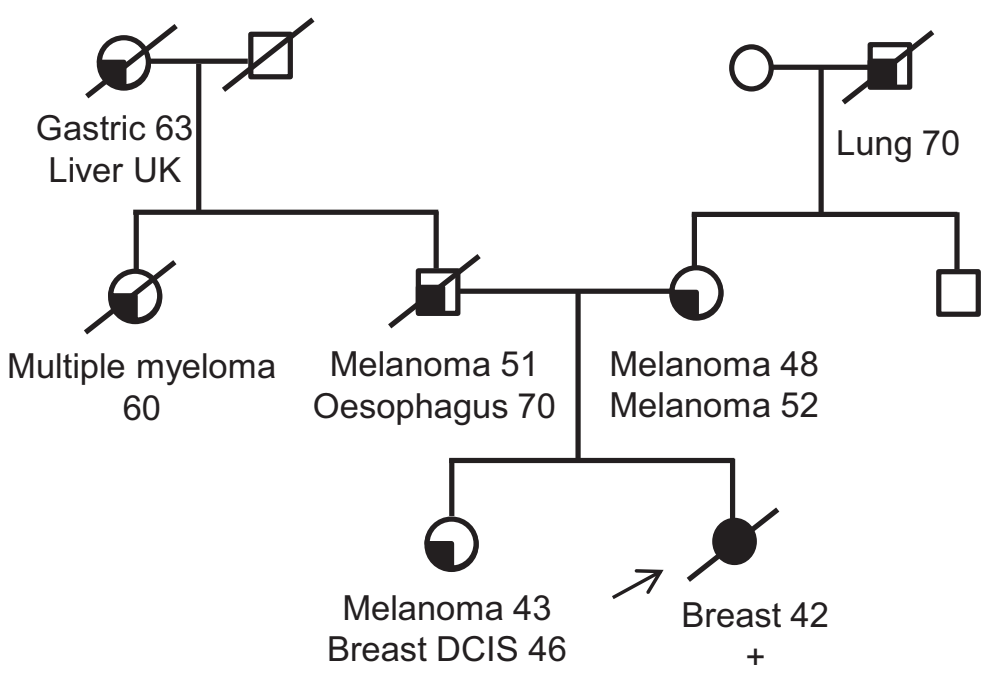




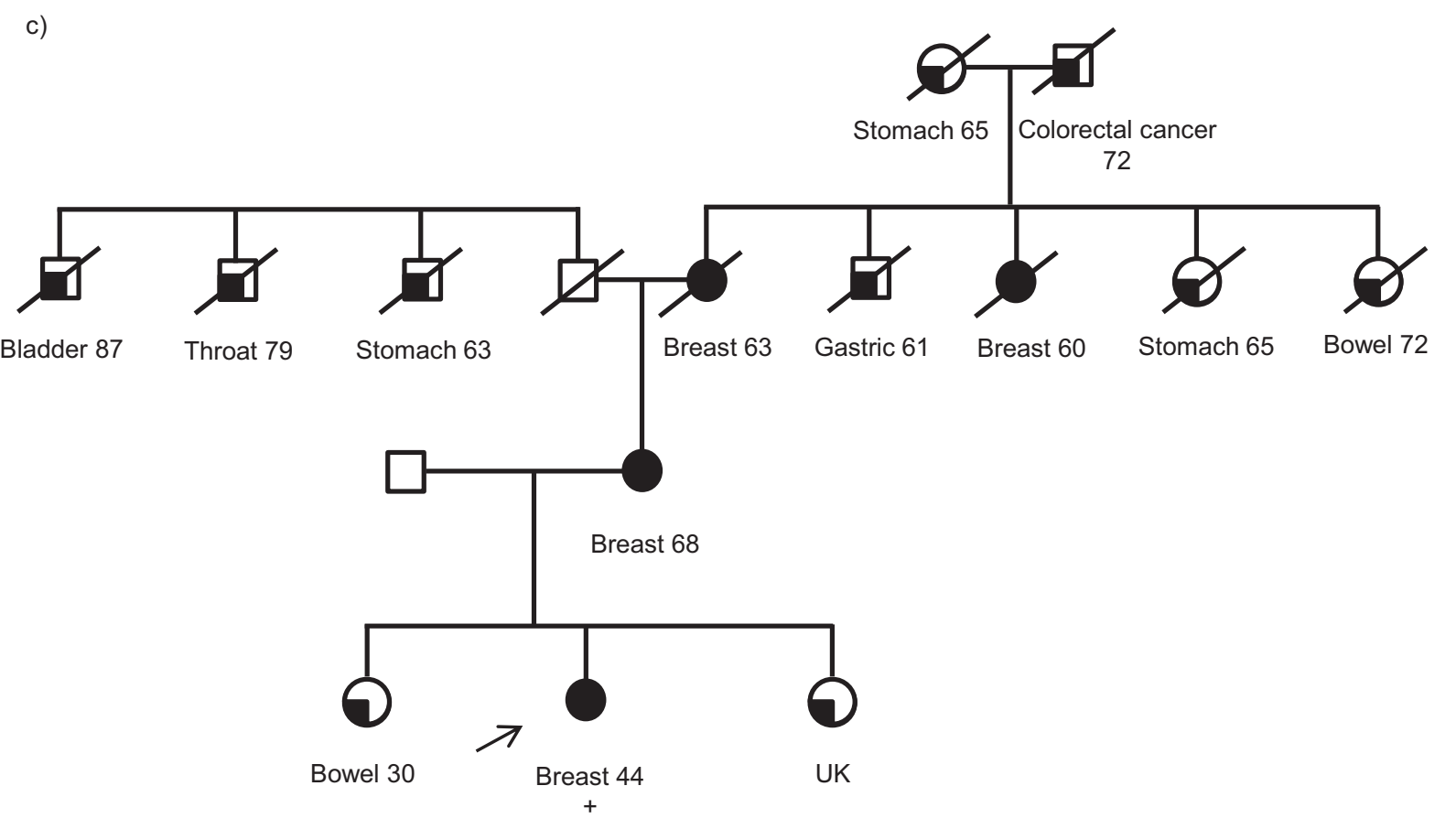

d) ${ }^{a}$

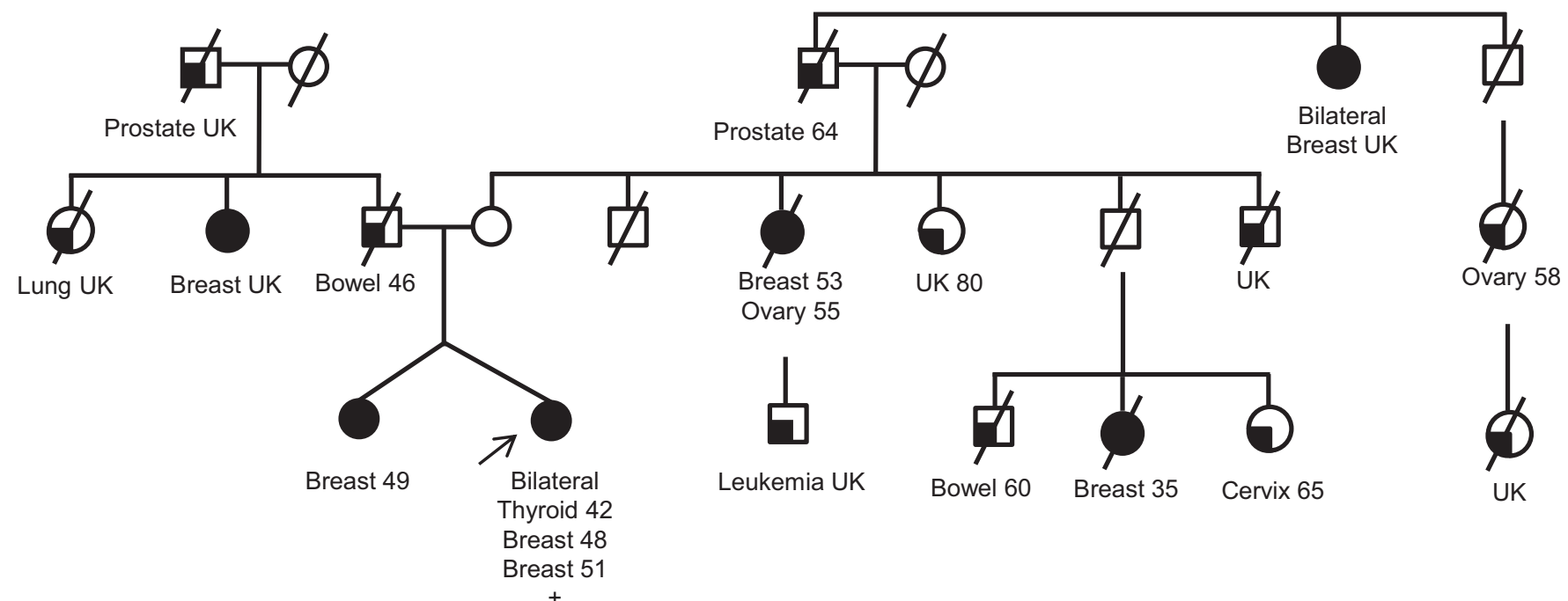


e)
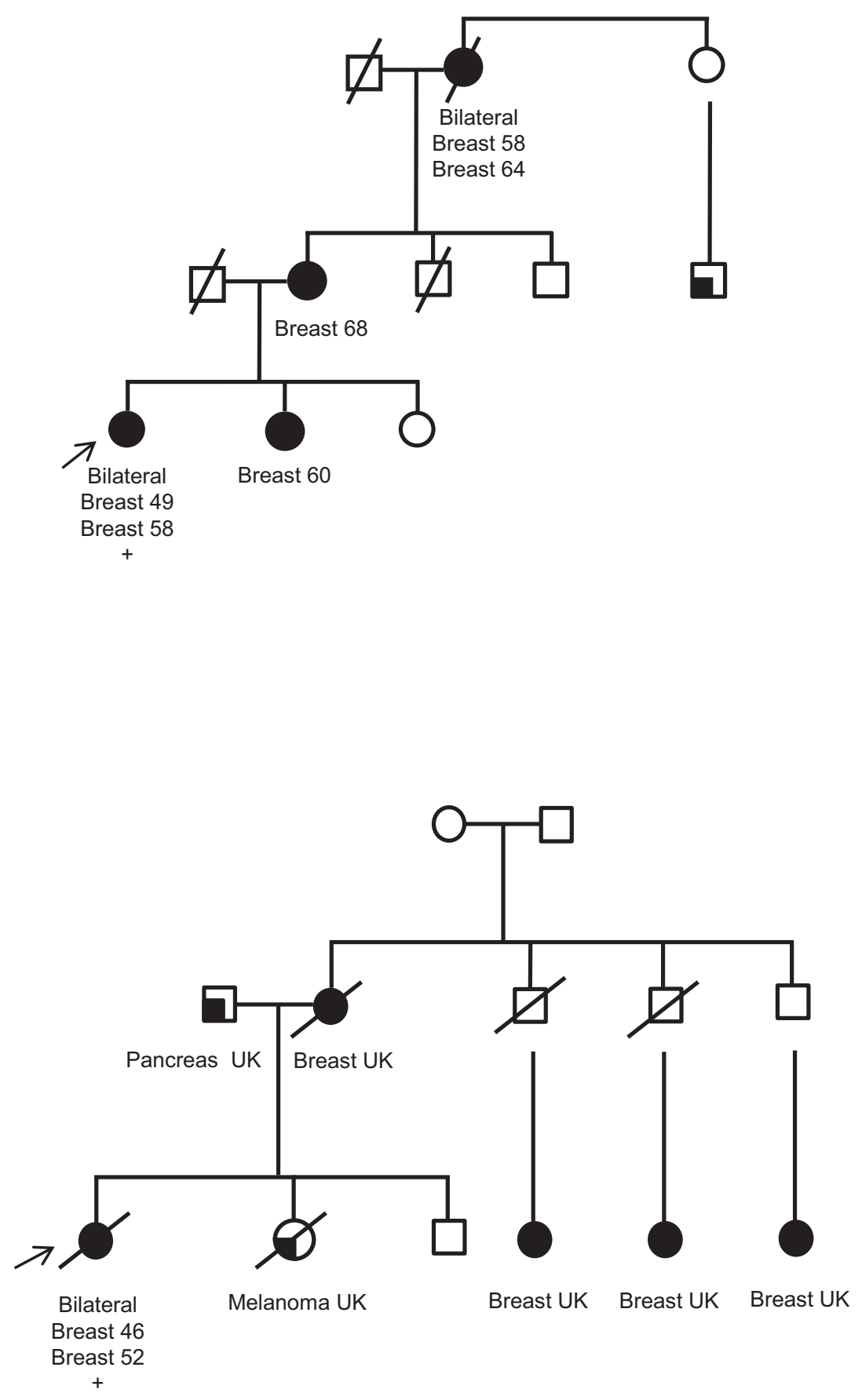
g)

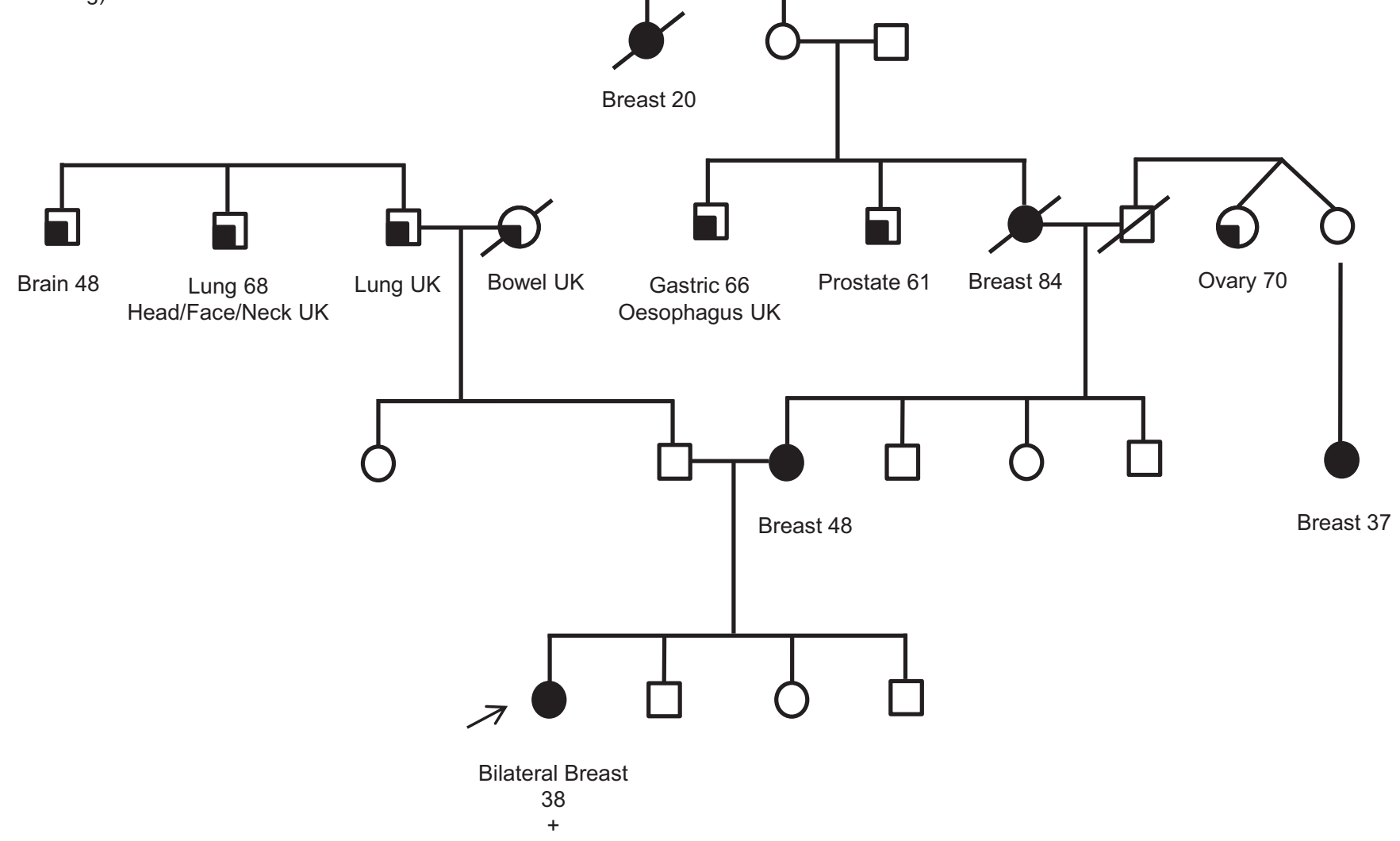

h) ${ }^{a}$

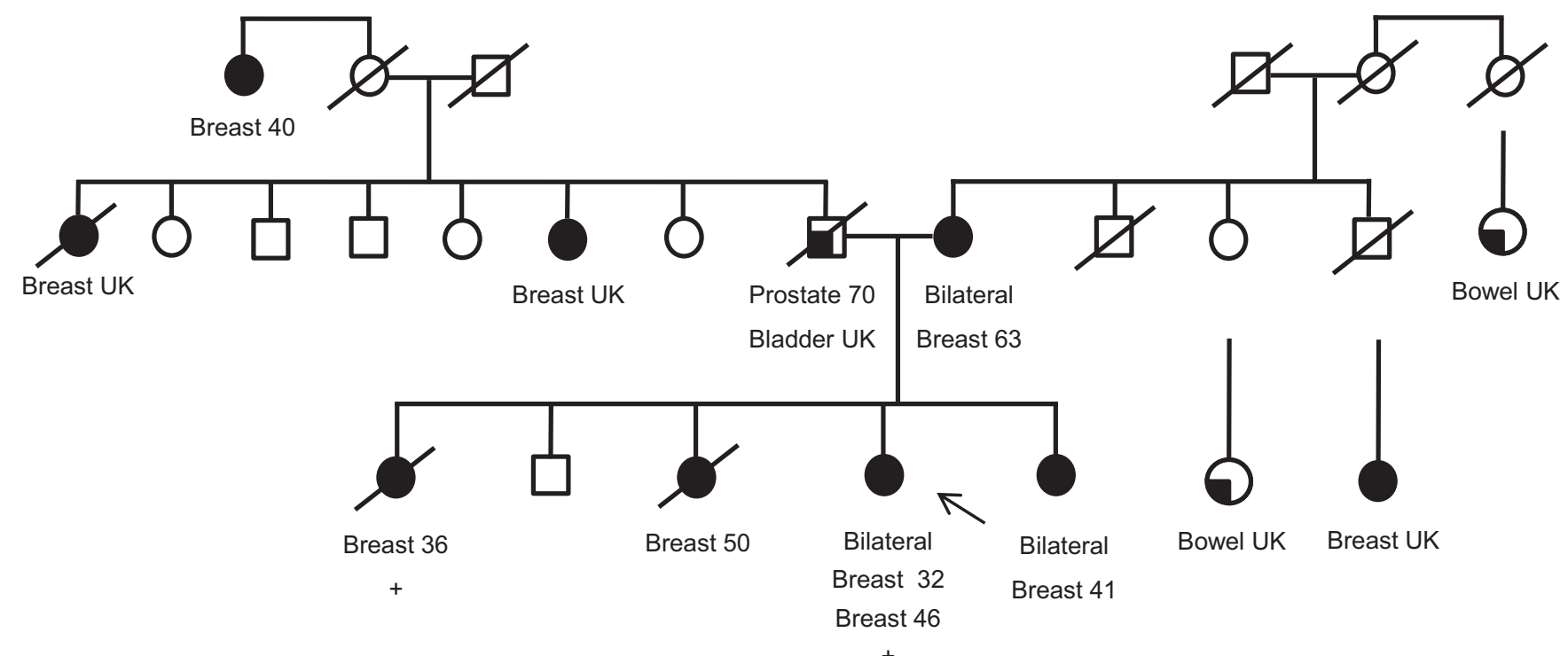

